\title{
Changing the Discourse: Post-Expulsion Jesuit Cartography of Spanish America
}

\author{
Mirela Altic \\ Institute of Social Sciences \\ mirela.altic@gmail.com
}

\begin{abstract}
The suppression of the Jesuit order influenced the overall production and content of post-expulsion Jesuit cartography, however, important differences in terms of content and discourse can be seen in terms of maps by former Jesuits created in Europe (esp. the Italian Peninsula and Central Europe) as well as the origin of Jesuit mapmakers (Creole / non-Creole). The reasons for this included the cartographic sources that the Jesuits used in exile, the new intellectual circles within which they exchanged geographic and cartographic knowledge, and the reception Jesuit maps had among former Jesuits as well as within European commercial cartography. Post-expulsion Jesuit cartography also had important impacts on intercultural transfers between Europe and the New World more generally. The study makes a comparative analysis of examples of the post-expulsion Jesuit cartography (manuscript and printed) from New Mexico, Chile, Paraguay, Quito, and Nueva Granada.
\end{abstract}

\section{Keywords}

Jesuit suppression - Jesuit cartography - Spanish America - Italian Peninsula German-speaking lands - Jesuit mapmakers (Creole / non-Creole) - knowledge transfer 


\section{Introduction}

Post-expulsion Jesuit cartography continued a long tradition of Jesuit mapmaking in the Spanish Americas that lasted almost three hundred years. ${ }^{1}$ Members of the Society of Jesus, more than other religious orders of early modern Europe valued maps and geography not only for the control of the missionary space but also as powerful presentations of their achievements in the terms of evangelization and cultural exchange. The Jesuit map had a dual mission, to represent both the power of the order and the colonial state. As Brian Harley has argued, it was a tool of visible persuasion accompanying their letters and relations that Jesuits sent back to Europe. ${ }^{2}$ Jesuits did not abandon that tradition during the post-expulsion period. Based on their unique first-hand knowledge, they continued to produce a significant number of narratives and maps. While the narratives published upon the suppression have been frequently studied, the Jesuit maps attached to these writings remain largely unexamined.

The suppression in Spain and in the Spanish colonies in 1767 was one of the last of the expulsions, with Portugal (1759) and France (1764) having already set the pattern. However, there were considerable differences in the way the suppression affected the Jesuits of the Spanish crown. Expelled from their South American missions and forced to live in exile, Spain still saw potential in the former members of the Society of Jesus. In order to persuade Rome to accept around 4,500 Jesuits exiled from the Spanish missions, the Spanish crown offered compensation to each displaced Jesuit. Thanks to that, numerous cities subsequently agreed to provide hospitality to Jesuits. Eventually, they doubled the amount of support for those Jesuits who agreed to publish their relations in which they would speak positively about Spanish crown policies. For the expelled Jesuits, this new form of service represented not only the possibility of at least some sort of rehabilitation, but also a significant means of supplementing their modest income. For the same reasons, the suppression of the

1 For the broader insight into the Jesuit mapmaking in Spanish America from the aspect of history of cartography cf. Guillermo Furlong, Cartografía jesuítica del Río de la Plata (Buenos Aires: Talleres S. A. Casa Jacobo Peuser, 1936) and David Buisseret, "Jesuit Cartography in Central and South America," in Jesuit Encounters in the New World:Jesuit Chroniclers, Geographers, Educators and Missionaries in the Americas, 1549-1767, ed. Joseph A. Gagliano and Charles E. Ronan (Rome: Istituto Storico, 1997), 113-62. For the same subject from the aspect of the history of science see Miguel de Asúa, Science in the Vanished Arcadia: Knowledge of Nature in the Jesuit Missions of Paraguay and Río de la Plata (Leiden: Brill, 2014).

2 Brian J. Harley, “The Map as Mission: Jesuit Cartography as an Art of Persuasion," in Jesuit Art in North American Collections, ed. Jane B. Goldsmith (Milwaukee: Patrick and Beatrice Haggerty Museum of Art, Marquette University, 1991), 28. 
Jesuit order in 1767 and their expulsion from the missions did not mean the end of the Jesuit cartography of Spanish America. Many of the Jesuit scholars and mapmakers continued their work, most in Central Europe and the Italian Peninsula rather than in Spain itself.

The Italian Peninsula, which became home to thousands of Jesuits expelled from their South American missions, proved to be particularly good environment for Jesuit scholars. Encouraged by the diverse cultural climates of the cities there and by Spanish financial support for the publication of their accounts, many Jesuits began to produce extensive writings. ${ }^{3}$ That Spanish offer became especially tempting once Pope Clement XIV (r.1769-74) banned the order in the Papal States (1773). Maria Theresa (r.1740-80) reluctantly followed suit in 1773, and the Holy Roman and Habsburg Emperor Joseph II (r.1741-9o) officially issued the Secularization Decree in 1782 . The result was closure of the domestic missions across the rest of Europe. Without status or stable sources of income, writing of accounts became a lucrative business for former Jesuits, and the inclusion of maps was an attractive selling point.

The Habsburg territories, including the Holy Roman Empire, subordinated to the Habsburgs under Joseph II, were second major area receiving the expelled Jesuits. Owing to the protection of Maria Theresa, the Jesuits continued to play an important role in the public life of the monarchy, especially in education and science, until as late as $1773 .{ }^{4}$ Accordingly, upon their expulsion from Spanish realms, the Jesuits from the German Assistance mostly returned to the countries of their origin where they continued to work as pastors, scholars or educators. Although, by virtue of the papal brief of 1773 (Dominus ac redemptor), their order was also suppressed in all Habsburg lands, the now already former Jesuits continued their activities in these lands after 1773 as well. Secured by pensions, they took opportunity to continue their careers outside of the banned order.

3 Clorinda Donato, "The Politics of Writing, Translating, and Publishing. New World Histories in Post-Expulsion Italy: Filippo Salvatore Gilii's 1784 Saggio di Storia Americana," in Jesuit Accounts of the Colonial Americas: Intercultural Transfers, Intellectual Disputes, and Textualities, ed. Marc André Bernier et al. (Toronto: University of Toronto Press, 2014), 50-80, here 53.

4 For more details on the historical context of the promulgation of the brief by Pope Clement XIV in the Habsburg monarchy, cf. Derek Beales, Enlightenment and Reform in EighteenthCentury Europe (New York: I. B. Tauris, 2005), especially his chapter "Maria Theresa, Joseph II and the Suppression of the Jesuits," 207-26. 


\section{Post-Expulsion Jesuit Cartography}

Compiled in a delicate period of political tension between Rome and Spain, the post-expulsion Jesuit maps created in Europe skillfully balanced between positions desirable for the Spanish crown and the pope. Just as the maps produced before the suppression, the post-expulsion Jesuit maps presented their (now already former) mission areas and were based on first-hand knowledge gathered during their missionary work in the field. However, as their authors were no longer representatives of power, the goals and symbolism of their maps changed significantly. Prepared in conditions of financial hardship, the decorating of maps with illustrations or rich cartouches was no longer possible. Maps were furnished simply, without much embellishment, especially not with those that could have been understood as a glorification of the suppressed order. Apart from leaving out the cartouches and ornaments that could be associated with their former power, they Jesuits also consistently avoided the symbols of the Spanish crown that had expelled them and banned their work.

The most obvious feature of the post-expulsion maps is the complete omission of the symbols of the Jesuit order. Although, in their narratives, former members of the order openly speak about their activities as Jesuit missionaries and about the history of numerous missions they had founded there before the suppression, the Jesuits and their order are not mentioned at all on the maps of these authors. Their former missions, which were taken over by members of other denominations, especially the Franciscans, are now only marked as missions or reductions on maps without attributing them to a specific religious order. The authors of maps also no longer sign their maps as missionary Jesuits, but neutrally as monks or pastors. The death places of Jesuit martyrs almost disappear from Jesuit maps as well. It was, of course, a kind of self-censorship allowing them to survive. When it comes to their manuscript maps from the post-suppression period, this self-censorship is not present. So the removal of the Jesuit symbols and traces in the space that would point to their missionary heritage was done as part of the preparation of post-suppression maps for print. The mention of Jesuit missions in the text was acceptable, but the marking of these same settlements as Jesuit missions on a publicly published map (even in the past tense) might have been understood as a pretension to their return, or even as a glorification of the order that had just been suppressed and accused of a plot against the king's life. A map is a stronger visual message than a text and as such politically more dangerous, so its censorship had to be stronger than the censorship of the narrative itself, of which the map was an integral part. Not one post-suppression Jesuit map was published as an unbound sheet. 
They remained within the narrative, folded among the pages and well-hidden by the book cover.

\section{The Italian Case}

The Jesuits in the Papal States were in a more difficult position than those in the Habsburg territories and Holy Roman Empire, because they constantly had to oscillate between staying in the good graces of the pope as well as the Spanish king, which resulted in a much stronger self-censorship of their printed maps. As a result, a significant part of the post-suppression Jesuit maps, though prepared for publication, remained in manuscript.

The Spaniard José Cardiel (1704-81), one of the most productive Jesuit cartographers, worked in Paraguayan missions for almost forty years. After the suppression, he settled in Bologna, then part of the Papal States, where he continued his study of Paraguay as well as his mapmaking endeavors. For the purposes of his narratives Breve relación de las misiones del Paraguay (1771) and Compendio de la historia del Paraguay (1780), he prepared several maps, which, along with his writings, remained unpublished. ${ }^{5}$ Two of his maps referred to a very sensitive issue- Jesuit landholdings in Paraguay. The first is a historical map that shows the exact spatial extent of Jesuit estancias in $1750 .{ }^{6}$ All the Guaraní missions, Spanish towns and demarcation of 1750 are designated, with the purpose of pointing out the crucial problem: after the implementation of the Madrid Treaty (1750), many of the vast Jesuit land properties remained on the Portuguese side. Although profitable estancias were returned to Spanish jurisdiction in 1761 , soon after the Jesuit expulsion they all collapsed, making this issue even more sensitive for the Spanish crown. His second map also shows Jesuit land properties with the Guaraní missions, pointing out their huge economic resources, another sensitive issue to raise in post-suppression time. ${ }^{7}$ However, although it is clear in both cases that these are maps of Jesuit missions and estates, on none of these maps are the Jesuits explicitly

5 These were only published in the twentieth century. José Cardiel, "Breve relación de las misiones del Paraguay, Faenza, 1771," in Organización social de las doctrinas guaraníes de la Compañía de Jesús, ed. Pablo Hernández (Barcelona: Gili 1913), 514-614; Cardiel, Compendio de la historia del Paraguay: 1780, ed. José María Mariluz Urquijo (Buenos Aires: Fundación para la Educación, la Ciencia y la Cultura, 1984).

6 Cardiel "Mapa de Las Doctrinas del Paraná y Uruguay, y de la Línea divisoria del año 1750 en cuanto a estas doctrinas toca," Papeles Varios.Tomo IV (203), Archivo Histórico de Loyola.

7 Cardiel, ["Mapa de las reducciones Guaraníes."] (1771), Archivo Histórico de Loyola. See Furlong, Cartografía jesuitica, 1:101. 
mentioned, nor do they contain any Jesuit symbols (the missions are marked as the poblaciones de Indios and the estates as the estancias, with no further attribution). Similarly Cardiel's third post-expulsion map shows the Gran Chaco and its missions. ${ }^{8}$ It is based on his 1763 map of Paraguay, which contains a clear statement of Jesuit presence. ${ }^{9}$ But his $177^{2}$ map retains no mention of Jesuit involvement, and only two locations of martyrdom are left (Figure 7.1).

A different statement can be recognized in another important postsuppression Jesuit cartographer, José Sánchez Labrador (1717-89), a great Spanish scholar in the field of natural sciences and missionary to the Guarani and Chiquitos, who continued his work in Ravenna, also under the rule of the Papal States. For the purposes of his narrative, El Paraguay católico, he prepared several maps to accompany his text. Atypical of post-suppression cartography, most of his maps, even though they do not contain any Jesuit symbols, explicitly mention the Jesuit missions and mark the death places of Jesuit martyrs. ${ }^{10}$ Given that his manuscript, just like Cardiel's, was not published in his lifetime, it is difficult to say whether Sánchez Labrador did not have time to adjust (censor) his maps for the printed edition or if he intended to print them in their original form. ${ }^{11}$ Accidently or not, in the version of the manuscript that was prepared for publication in 1910, only two of Sánchez Labrador's maps are attached: his map of the Paraguay River downstream of Belén, and a map of the Paraguay River upstream of Asunción, exactly those that did not contain explicit mention of the Jesuits. Based on his 1766-67 expedition along the upper Paraguay River, these explorative maps focused solely on physical geography.

8 Cardiel, "Mapa del Chaco, que se comprehende entre el Río Paraguay, Missiones de Chiquitos, prov. De S. Cruz, Charcas, Chichas, Tucuman, y Rio dela Plata. Año 1772," 2-2-30, Archivo Histórico de Loyola.

9 Cardiel (attrib.), "ins/Parte de la América Meridional en que trabaja el zelo de los Religiosos de la Compañía de Jesús de la Provincia dicha del Paraguai," in Pedro de Calatayud, Tratado sobre la Provincia de la Compañía de Jesús en el Paraguay, Box 17, no. 3, Archivo Histórico de Loyola. See Furlong, Cartografía jesuítica, 1:97-98.

10 Cf. Sánchez Labrador's maps, "Província del Itatin convertida a la Fé por los Jesuitas y destruida por los Mamalucos" reproduced in Furlong, Cartografía 2, plate 45; and "Provincia del Guayrá convertida por los Jesuitas y destruida por los Mamalucos Portugueses," reproduced in Furlong, Cartografía 2, plate 42; and "Missiones del Tape en la forma que tenían antes de su transmigración el año, 1630," reproduced in Furlong, Cartografia 2, plate 44 .

"El Paraguay católico," which survives in several slightly different manuscript copies, is accompanied with maps whose number varies from copy to copy. Parts $2-3$ of the manuscript were published by Samuel A. Lafone Quevedo, ed., El Paraguay católico (Buenos Aires: Coni, 1910). The first volume of his manuscript remains unpublished. 


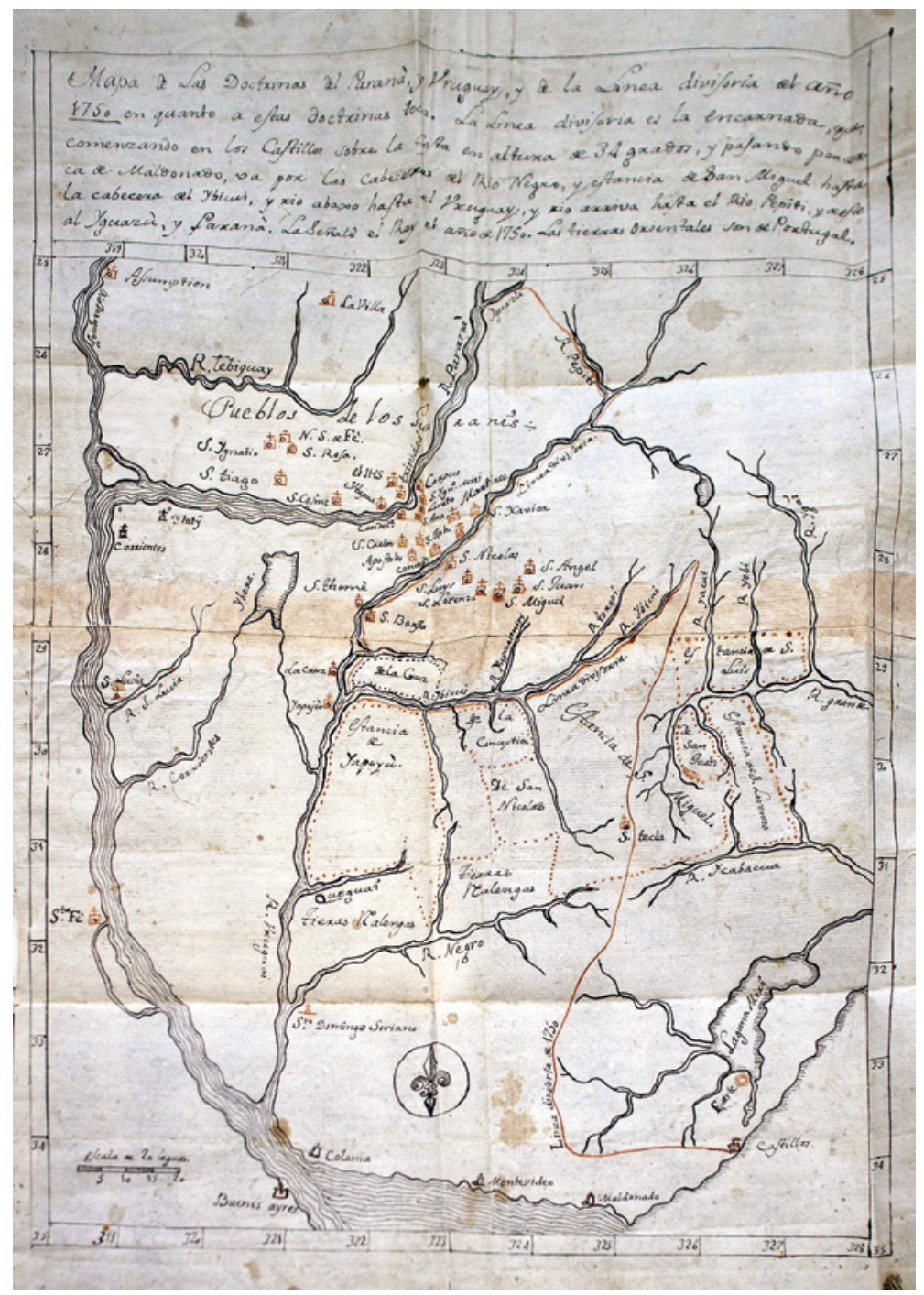

FIGURE 7.1 José Cardiel, Mapa de las doctrinas del Paraná y Uruguay, y de la línea divisoria del año $175^{\circ}$ en cuanto a estas doctrinas toca, created in Bologna, 1772. This manuscript map testifies to self-censorship of the post-exile Jesuit maps as a part of their preparation for publishing. It addresses the sensitive issue of Jesuit landholdings in Paraguay and Guaraní missions after the Treaty of Madrid without mentioning the Jesuits.

ARCHIVO HISTÓRICO DE LOYOLA, PAPELES VARIOS.TOMO IV (203) 
In contrast to Sánchez Labrador, some censorship can be noticed in the cartographic work of Filippo Salvatore Gilii (1721-89). Born in the Papal States, Gilii was not a typical exiled Jesuit-after the suppression, Gilii returned to the town of Legogne, eventually dying in Rome. Gilii's double profile as a Jesuit under Spanish control and a Jesuit from the Papal States gave him a unique cultural discourse. ${ }^{12}$ His intellectual circle included many prominent Creole Jesuits who were working in Italian exile, such as Juan Ignacio Molina (1740-1829) and Francisco Javier Clavijero (1731-87) in Bologna, and Juan de Velasco (1727$92)$ in Faenza, all in the Papal States. While compiling his book, Saggio distoria americana (Rome, 1780-84), Gilii included several maps. One of them shows the region between the Amazon and the Orinoco ${ }^{13}$ (Figure 7.2). By focusing his

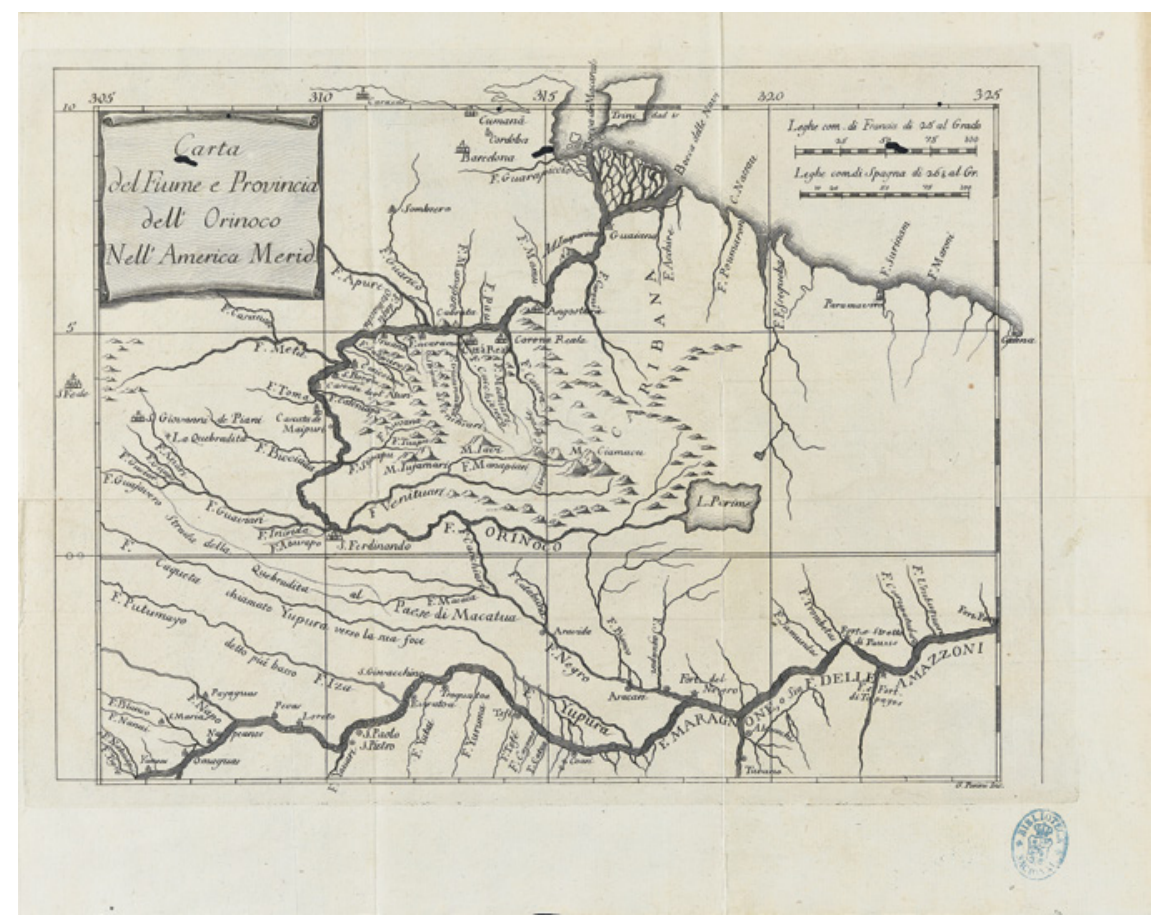

FIG URE 7.2 Filippo Salvatore Gilii, Carta del fiume e provincia dell' Orinoco nell' America Merid [ionale] (Roma: Luigi Perego Erede Salvioni, 1780). This map highlights the physical geography of the space as having important economic resources, leaving human geography, a much more sensitive issue, in the background. NATIONAL LIBRARY OF SPAIN (BNE), 2/68896

12 Donato, "The Politics of Writing," 53.

13 [Carta del fiume e provincia dell'Orinoco nell'America Merid[ionale] Saggio di storia americana 1 (Roma: Luigi Perego Erede Salvioni, 1780), after xiv, National Library of Spain (BNE), 2/68896. 
presentation exclusively on the Orinoco, a region in which the Jesuits acted as a most effective tool of colonial power, the author discreetly put the merits of the Jesuits before the power of the colonial state, without mentioning their name. However, his approach to the presentation of the space clearly reflects the changes in post-suppression Jesuit thinking. His map primarily presents the important features of physical space that could further the development of the colonial economy, leaving human geography, a much more sensitive issue, in the background. Gilii's discourse on tropical nature addresses the relationships between Enlightenment natural science, geography and colonial politics. ${ }^{14}$ His statement is confirmed by the explanation key that designates only Spanish cities, forts, and some of the missions without their affiliation. With his map Gilii offers missionary knowledge on the region that can help the Bourbons to attain economic order, omitting any sensitive issues that could put him or his publication in danger.

\section{The German Case}

The Habsburg territories and the Holy Roman Empire, which, under the influence of Maria Theresa, had a more tolerant attitude towards the Jesuits after the suppression of the order, did not have such a strong censorship. That enabled the former Jesuits to have a freer relationship to the use of symbols on their maps after 1773 as well. The first significant Jesuit narrative published in German after the suppression was the posthumous translation of Miguel Venegas's (1680-1764) Natürliche und bürgerliche Geschichte von Kalifornien $(1769-70)$. It was revised and published by the Jesuit historian Andrés Marcos Burriel y López (1719-62) in Madrid (1757) and subsequently appeared in London (1759) and Paris (1767). The German edition was translated by the old and famous publishing house of Meyersche Buchhandlung run by Johann Henrich Meyer in Lemgo, a city that by treaty could determine its own brand of Protestantism distinct from the rule of Calvinist Lippe. For the German edition, the map of Baja California, based on templates by Ferdinand Konščak and Eusebio Kino and appearing in various forms all of the editions, made important changes from the French model. The Jesuit monogram, which in the form of the sun shone over California, symbolically emphasizing the Jesuit role in

14 Santa Arias, "The Intellectual Conquest of the Orinoco: Filippo Salvatore Gilij's Saggio di storia americana (1780-1784)," in the special issue "Troubled Waters: Rivers in Latin American Imagination," ed. Elisabeth M. Pettinaroli and Ana Maria Mutis, Hispanic Issues On Line 12 (2013): 55-74, here 65. 
these areas, was removed from the map in every edition but the original Spanish. However, the Jesuit authorship, emphasized in the title of the map, was retained as well as the dedication to the Spanish king, but now without heraldic symbols. ${ }^{15}$ With similar interventions, Jacob Baegert included a Latin version of the same map in his work titled, Nachrichten von der amerikanischen Halbinsel Kalifornien (1773) in Mannheim, capital of the Palatinate and Bavaria. ${ }^{16}$ Baegert did not hesitate to go one step further, pointing to the places of Jesuit martyrdom as well as to his departure route taken upon the expulsion.

The first edition of Jesuit narratives furnished with a map after the suppression of the order in 1773 was published in Münster in 1777 (Figure 7.3). Its author Bernhard Havestadt (1714-81), a Rhineland Jesuit from Köln, served among the Araucanians for almost twenty years. He settled down in Vienna after the suppression, where he continued to work on his survey of the Chilean language. While preparing his work, Chilidúgu sive res Chilenses, for publication, he also supplemented it with his map of the Araucanian and Transandine missions, which he compiled in $175^{2}$ based on his travel experience and exploration. ${ }^{17}$ The map was published without any intervention, so it included a

15 “Carte de la Californie: Levée par la Société des Jésuites; Dédiée au Roy D’Espagne en 1757," Natürliche und bürgerliche Geschichte von Californien: nebst einer neuen Charte dieses Landes und der benachbarten Meere Dritter und letzter Theil 1 (Lemgo: Meyerschen Buchhandlung, 1769), facing title page. It used a unique cartouche but was taken from the French edition of the same work, Histoire naturelle et civile de la Californie, contenant une description exacte de ce pays, de son sol, de ses montagnes, lacs, rivières \& mers, de ses animaux, végétaux, minéraux, \& de sa fameuse pêcherie des perles 1 (Paris: Chez Durand, 1766), facing 1 . The English edition also removed the Jesuit iconography and used an elaborate and exoticized cartouche, A natural and civil history of California: containing an accurate description of that country, its soil, mountains, harbours, lakes, rivers, and seas (London: Printed for James Rivington and James Fletcher, 1759), between 12 and 13 . The Spanish edition is Noticia de la California y de su conquista temporal y espiritual hasta el tiempo presente, sacada de la historia manuscrita formada en México año de 1739 por el Padre Miguel Venegas de la Compañía de Jesús, y de otras noticias y relaciones antiguas y modernas (Madrid: Manuel Fernandez y del Supremo Consejo de la Inquisición, 1757), facing 1 , which surrounded the map with figures of people and animals.

16 "Californiae per P. Ferdinandum Consak S. I. et alias," in Nachrichten von der amerikanischen Halbinsel Kalifornien (Mannheim: Churfürstl. Hof- und Academie-Buchdruckerey, 1773), before 1 .

17 "Mappa Geographica exhibens Provincias, Oppida, Sacella \&c quae Mensibus Novembri ac Decembri anni $175^{1}$ et Januario Februario et Martio anni $175^{2}$ peragravit ad Indorum Chilensium terras excurrens P. Bernardus Havestadt é Soc. Jesu Missionarius" (Münster: Hieronymus Strübel, 1777), Archive of Early American Images, J777 H387c., John Carter Brown (JCB). 


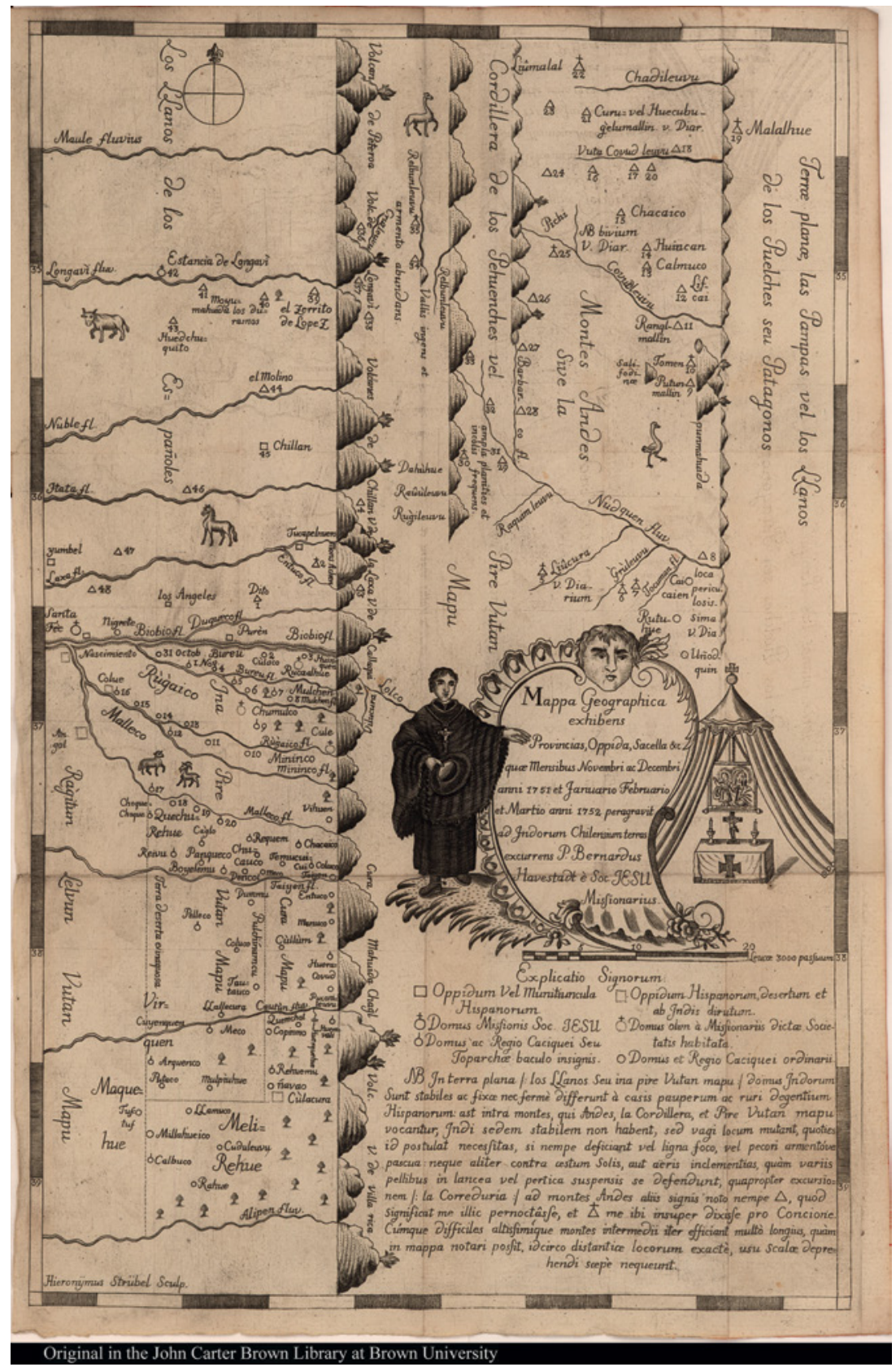

FIG URE 7.3 Bernhard Havestadt, Mappa Geographica exhibens Provincias, Oppida, Sacella \&c quae Mensibus Novembri ac Decembri anni 1751 et Januario, Februario et Martio anni $175^{2}$ peragravit ad Indorum Chilensium terras excurrens P. Bernardus Havestadt é Soc. Jesu Missionarius (Münster: Hieronymus Strübel sculp., 1777). A rare example of the post-exile map with full Jesuit iconography JOHN CARTER BROWN, ARCHIVE OF EARLY AMERICAN IMAGES, J777 H387C 
representation of the Jesuit missions and a cartouche with an illustration of a Jesuit missionary, the most striking (and perhaps the only) example of absence of censorship in the post-suppression period.

Martin Dobrizhoffer (1717-1791), a Jesuit who spent many years in Paraguayan missions, settled in Vienna upon the suppression, obtaining the friendship of Maria Theresa. To accompany his 1784 Historia de Abiponibus, he produced three maps and relied on his own observations. ${ }^{18}$ Although, in his narrative, Dobrizhoffer openly paid tribute to the Jesuit contribution in the development of the region, on his map, he excluded the mention not only of the former Jesuit presence but also of the Franciscans who took over most of their former missions (all the missions are designated neutrally as pagum). The suppression affected the decoration of the map as well, thus, instead of the usual Jesuit anagram, the map includes only the royal coat of arms of Spain.

After the death of Maria Theresa, the social climate in the Habsburg territories was increasingly less well disposed towards the Jesuits, so, after 1780 , the publishing activity of the former Jesuits became more directed towards the independent cities and states of the Holy Roman Empire. Franz Xavier Veigl (1723-98), a former superior of the Marañon missions who, upon the suppression, settled down in his native Austria, decided to publish his accounts, Gründliche Nachrichten über die Verfassung der Landschaft von Maynas in SüdAmerika bis zum Jahre 1768 (1785) with Johann Eberhard Zeh (1739-1807) in Nürnberg, a city caught between the influence of Bavaria and Prussia. Although heavily edited, the printed version of Veigl's map, attached to his narrative, kept the Jesuit designation of the missions as well as the Jesuit-Franciscan jurisdictional delimitation south of the Putumayo River. ${ }^{19}$ However, the decorative

18 Dobrishoffer's maps are: "Mappa Paraquariae in multis a me Correcta. Quid si in pluribus porro per alios Corrigenda; Mappa regionis Taruma \& Mbaéverá," in Historia de Abiponibus 2 (Vienna: Josephi Nob. de Kurzbek, 1784); and "Colonia Abiponum a Rosario \& S Carolo dicta A Barbaris Mocobiis, Tobis \& Oaekakalotis Equitibus Circiter Sexcentis oppugnata anno 1765 die 2 Augusti," vol. 3 , following 356 .

19 See Veigl's manuscript map of the Marañón missions, which he compiled during his imprisonment in Lisbon in 1769. It is known only from a reproduction. The printed version of Veigl's map was edited by Petro Parcar in 1780 and published within Veigl's account in 1785. "Maragonii sive Amazonum Fluminis Terrarum in Orbe Maximi, quoad Hispanicae Potestati subset, Cursus cum Fluviis et Regionibus finitimis utilitati publicae, probatissimis e Documentis accuratius novissime descriptus a quodam per eas provincias olim S.I.Missionario delineates a Petro Parcar 1780," in Reisen einiger Missionarien der Gesellschaft Jesu in Amerika, ed. C. G. von Murr (Nürnberg: Johann Eberhard Zeh, 1785), JA785 R375e, јсв Map Collection. 
cartouche is fully devoted to the church and colonial administration, without any evocation of the Jesuits.

\section{Creoles versus Non-Creoles}

The expelled Jesuits of Creole descent who, along with the non-Creoles, found themselves in exile in the Papal States, did not only lose their former missions, but also their own homeland. This loss caused them to emphasize the need to maintain their own identity, which they were trying to express through their scholarly work as well. But when it comes to maps, like their non-Creole colleagues, they had to be extremely careful, expressing their nostalgia for their homeland through discrete symbols and hidden messages. When the Chilean Jesuit Juan Ignacio Molina (1740-1829) compiled his map of Chile in Bologna for the purpose of his narrative, Compendio della storia geografica, naturale, $e$ civile del regno del Chile (1776), it did not depart from the conventions of postsuppression cartography ${ }^{20}$ (Figure 7.4). Unlike Havestadt, Molina removed all the elements that would associate his map with the Jesuit order. The only reminiscence of Jesuit activity in that area is the cartouche decorated with a statue of an Araucano Indian. His Argentine counterpart, Joaquín Camaño y Bazán (1737-1820), acted likewise. When compiling his map of Paraguay in Faenza, which was published in José Jolis's (1728-1790) Saggio sulla storia naturale del Gran Chaco (1789), he excluded all the elements that would refer to Jesuit heritage. ${ }^{21}$ Although attached to the narrative that clearly describes the former Jesuit province, in order to be neutral, the designated missions on the map are not further attributed.

A creole who, during his exile, undoubtedly most directly expressed his feelings towards his lost homeland was Juan de Velasco (1727-92), who also continued to work in Faenza after the expulsion. While working on his narrative, Historia del Reino de Quito, written in patriotic fervor, Velasco supplemented his manuscript with a map. ${ }^{22}$ Velasco's map, which depicts the actual

20 [Juan Ignacio Molina], "Il Chile Regno dell'America Meridionale," in Compendio della storia geografica, naturale, e civile del regno del Chile (Bologna: S. Tommaso d' Aquino, 1776), facing $1, \mathrm{H}_{77} 6$ M722c, Jсв Map Collection.

21 Joaquin Camaño, "Carta del Gran Chaco y Paesi Confinanti. Delin. dal Sig. Ab. Gioachino Camagno," in José (Giuseppe) Jolis, Saggio sulla storia naturale del Gran Chaco (Faenza: Lodovico Genestri, 1789), facing 21, Giuseppe Ballanti, engraver.

22 Juan de Velasco, "Carta general de las provincias del Quito Propio de las orientales adjuntas y de las Misiones del Marañón, Napo, Pastaza, Guallaga, y Ucayale delineada Según las mejores Cartas modernas y observaciones de los Académicos y Misioneros, por el Presb. 


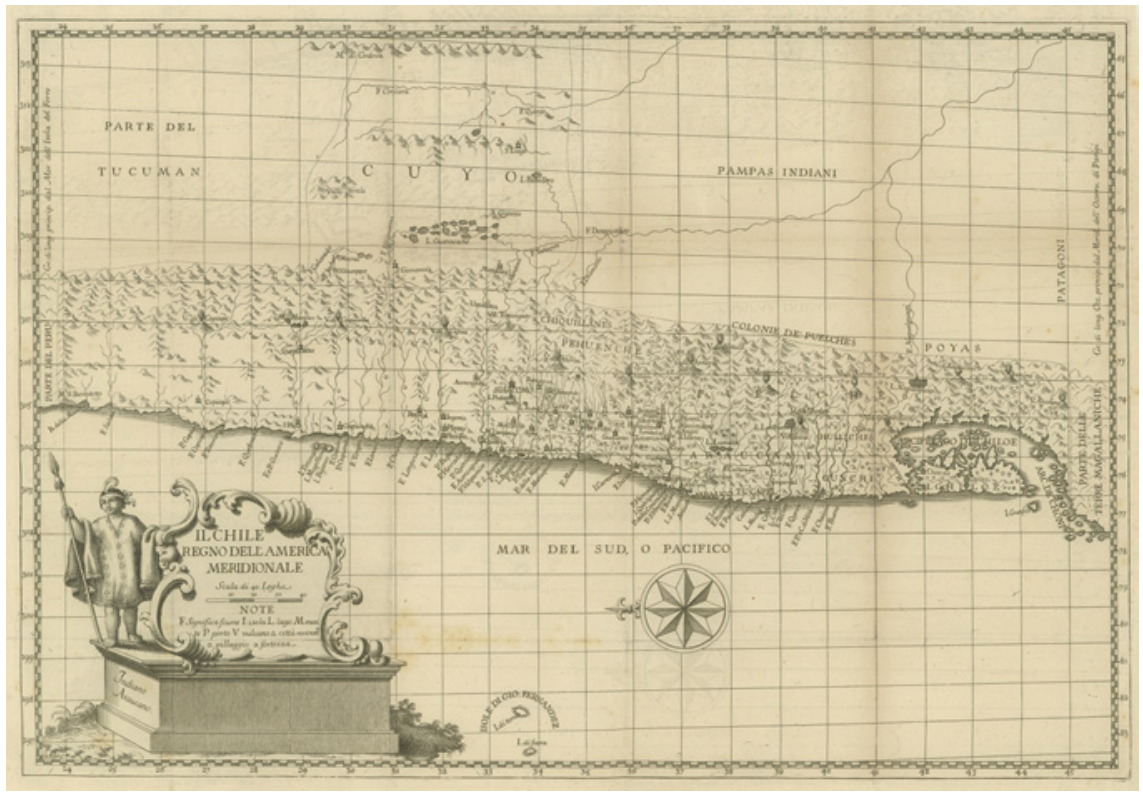

FIGURE 7.4 Juan Ignacio Molina, Il Chile Regno dell'America Meridionale (Bologna:

S. Tommaso d'Aquino, 1776). Produced by a creole author, this map meets typical conventions of post-suppression cartography. Elements associating the map with the Jesuit order are removed. The only reminiscence of Jesuit activity is the cartouche of the Araucano Indian.

JOHN CARTER BROWN, MAP COLLECTION, HTT6 M722C

territorial extent of Quito in the eighteenth century, serves as a counterpoint to his narrative describing the extent and glory of the former kingdom that occupied a significantly larger area. In this sense, by depicting what remained of the territory of Quito, Velasco actually stresses how much territory was lost. Velasco believed that it could have been saved by Jesuit missions and economic reforms in which the Creoles would play a key role. Although it includes a representation of the missions within a colonial province of the Spanish empire, Velasco's map is not missionary map. Its pronounced ideological engagement classifies it among maps with political, or proto-national, characteristics. He depicts space as an important determinant of the identity. His envisioning of the prime meridian passing through Quito is for Velasco above all an expression of patriotism. Placing Quito at the intersection between the equator and

D. Juan de Velasco, para servir a su Historia del Reino de Quito. Año de 1789," in Historia del Reino de Quito en la América meridional 1 (Quito: Imprenta del Gobierno, 1844). Scale ca 1: 1,460,000. 
the prime meridian, he defines Quito not only in terms of identity, but also geographically as the center of the world.

Although he does not explicitly mention the Jesuits on the map, it is nonetheless also a monument to Jesuit achievements in Quito, both in the development of the local economy of the missions and in the exploration and mapping of the hardly penetrable regions of the upper Amazon. Velasco shares the conviction that the Jesuits are the perfect instruments for instilling civilization and unifying the territory. The map graphically illustrates how the Spanish crown has abandoned strategies and its strategists (the Jesuits) who knew how to produce desired results. ${ }^{23}$ Entirely inconsistent with the expectations of the colonial authorities, Velasco's narrative was completed in 1789. Together with the map, it remained in manuscript until 1844 when it was first published in Quito. Thus, the only relatively uncensored post-suppression map originating from the pen of a Creole remained unpublished, carefully hiding the discourse that equally glorified Jesuit merits as well as the rootedness of the Creole identity as the foundation of the future nation.

\section{Echoes of Post-Suppression Jesuit Cartography in the European Enlightenment}

In Jesuit cartographic works created after 1767 , a stagnation in geographic knowledge can be noticed. After the Jesuits had left for Europe, more recent official colonial maps were not available to them anymore, especially not those of military character or the results of recent expeditions. As sources for their maps published in Europe in the post-suppression period, Jesuit cartographers use almost exclusively maps and reports of their fellow Jesuits dating back to 1767 . Undoubtedly aware of the growing obsolescence and insufficiency of their data, and pressed by the increasingly popular competitive editions of commercial cartography, the Jesuits openly criticized the editions of European cartography. To highlight the credibility of their maps, Jesuit cartographers in exile invoke their empirical knowledge, because that is exactly what gives them the advantage over other European scientists. ${ }^{24}$ Therefore, the post-suppression Jesuit maps were based on criticism of the existing maps

23 Eileen Willingham, "Literary Patriotism in Ecuador's Juan León Mera and Juan de Velasco," Humanities Research 17, no. 1 (2011): 21-34, here 31.

24 "An eyewitness represents more value than ten ear-witnesses. Those who only hear, say merely what they have heard; those who see, know it with certainty." Martin Dobrizhoffer, Historia de Abiponibus 1 (Vienna: Typis Josephi Nob. de Kurzbek, 1784), 2. 
produced by non-Jesuits and conceived as an explicit counter-discourse to the existing one..$^{25}$ Pointing to the fact that only the maps created based on firsthand knowledge and personal testimony can have a true scientific foundation, they tried to secure authority over the ever more numerous maps of European travelers and explorers.

To enable the exchange of knowledge necessary for their map production, former Jesuits from the Spanish dominions organized an informal network of mutual support. However, even this group was not free from internal conflicts. For example, Camaño strongly criticized José Quiroga's mapmaking achievements as simplified geography learned in a hurry from his midshipmen. On the other hand, he highly appreciated the work of Sánchez Labrador, Buenaventura Suárez and José Cardiel. The tensions between some of the Jesuits in exile affected the sources that some Jesuits chose to use or to ignore. The reluctance of Jesuit cartographers to improve their research results with new results of the scientists outside their circle and their mutual competition made errors, even in the placing of individual missions, increasingly pronounced, while the mathematical basis of entire maps were often comparatively deficient. Although some of the works of Jesuit missionaries furnished with maps would continue to be issued until as late as the early nineteenth century, they would no longer cause significant attention of the European scientific public. ${ }^{26} \mathrm{Nev}-$ ertheless, during the nineteenth century, the Jesuit narratives, especially those charged with proto-national sentiments, would once again come into the focus of interest, this time in the South American countries themselves. Associated with accounts about local nature, Jesuit writings as well as their maps significantly contributed to the upsurge of South American nationalisms, affirmed as an important source for defining local identities and fighting against deeply ingrained Eurocentric understandings of the Americas.

25 That refers to their narratives as well. Cf. Hans-Jürgen Lüsebrink, "Between Ethnology and Romantic Discourse: Martin Dobrishoffer's History of the Abipones in a (Post)modern Perspective," in Jesuit Accounts of the Colonial Americas: Intercultural Transfers, Intellectual Disputes, and Textualities, ed. Marc André Bernier et al. (Toronto: University of Toronto Press, 2014), 127-43, here 130.

26 E.g. Javier Iturri (1738-1822) attached a Camaño's map of Viceroyalty of the Río de la Plata to his narrative Historia natural, eclesiástica y civil del Virreinato del Río de la Plata (1798). 